\title{
The Distribution of certain Portions of the British Flora.
}

\section{Plants restricted to England and Wales.}

BY

\author{
J. R. MATTHEWS, M.A., F.L.S., \\ Royal Botanic Garden, Edinburgh.
}

With six Diagrams in the Text.

\section{INTRODUCTORY}

THE flora of the British Isles, although a comparativaly limited one, 1 presents many interesting problems in plant-geography. These problems, as is well known, have been discussed from time to time, especially since Edward Forbes (1846) dealt with them in a classic memoir, 'On the Connexion between the Distribution of the existing Fauna and Flora of the British Isles and the Geological Changes which have affected their Area'. Forbes, an advocate of overland migration, recognized five distinct subfloras and explained their distribution in Britain as a result of successive invasions from the extensive land mass lying eastward, prior to the detachment of Britain from the European mainland. The composition of our flora was also the subject of prolonged study by H. C. Watson (1835, 1847), and largely to his labours, too, we owe a careful analysis of the distribution of our native plants as presented in 'Topographical Botany' (1883). Some of the 'types of distribution' formulated by Watson have been discussed and defined with greater precision in an interesting paper by Stapf (1914), while Moss (1914), in a general account of plant distribution in Britain, brings the work of Forbes and Watson into line with that of recent authors.

All writers on the subject are generally agreed that the British flora is essentially a reduced continental flora, derived from the Continent in relation to past climatic changes, yet there is no unanimous opinion regarding the time and method of arrival of its several elements. A decisive answer cannot easily be given to these questions, for the historical succession is incomplete. A glance at the position, however, may not be without interest. 


\section{Historical Phytogeography.}

The problem of the origin of the British flora was attacked by Clement Reid (1899), employing the historical method, but the imperfection of the fossil record made a final conclusion exceedingly difficult. Since that date our knowledge of Pliocene and Pleistocene floras has materially increased. The researches of C. and E. M. Reid (1908) and those of E. M. Reid $(1920 a)$ on pre-glacial floras of Western Europe provide reliable evidence of the nature of the vegetation of this country before the onset of the Pleistocene, when the character of the flora underwent a decided change. A comparative review of West European Pliocene floras is given by E. M. Reid (1920 b), who shows that the flora during this period changed from one having a high percentage of exotic species, many of which are Chinese-North American, to a flora (represented by the Cromerian at the top of the Pliocene) about 95 per cent. of which is composed of species which inhabit East Anglia at the present day. The author refers to a suggestion made in an earlier paper (1915) in which it is stated that the high land of Central Asia may have acted as a second centre for the origin and dispersal of temperate species in Miocene and Pliocene times, and is led to make the further suggestion that ' much of the living flora of the lowlands of Western Europe has been derived from this source, by dispersal through the Near East, the Caucasus, and the mountains of Southern and Central Europe, or by way of the Mediterranean '. The identity of most of the Cromerian flora with species now occurring in England has been mentioned, and, were it not for the onset of a period marked by increasing cold, there would have been probably no special difficulty in tracing the progressive emergence of our flora to its present state. But the change from heat to cold which culminated in the Ice Age produced a migration southwards, and the central problem of distribution in Britain turns entirely on the course of events throughout this period of climatic change. Information as to what exactly happened during the time of maximum glaciation would provide a definite starting-point in any attempt to solve the problem, but unfortunately the geological record is inconclusive.

There is, however, a steadily increasing body of evidence to show that a redistribution of vegetation must have occurred during Pleistocene times, since in place of the temperate flora which inhabited the south of Britain at the close of the Pliocene we find post-Pliocene fossil floras containing a very pronounced arctic element. The early records of glacial plant-bearing deposits are enumerated by C. Reid (1899), who gives full details, and we shall here refer only to two recently described arctic floras from low latitudes in England. Reid (1916) gives a list of the plants of the late glacial deposits of the Lea Valley, 22 per cent. of which are arctic species. The arctic flora revealed by Marr and Gardner (1916) at Barnwell in the Cam Valley and 
referred to a late, if not the latest, stage of the Pleistocene deposits of the district has been fully studied by Chandler (1921), who finds that 42 per cent. of the species are arctic-alpines. Of these the following are worth noting :

Ranunculus aconitifolius, L., Papaver alpinum, L., Draba incana, L., Arenaria sedoides, L., Arenaria biflora, L., Potentilla alpestris, Hall., P. fruticosa, L., Dryas octopetala, L., Saxifraga oppositifolia, L., Vaccinium uliginosum, L., Primula scotica, Hook., Armeria arctica, Wallr., Salix Arbuscula, Fries., S. Lapponum, L., S. herbacea, L., S. polaris, Wahl., S. reticulata, L., Betula nana, L., Carex lagopina, Wahl., C. ustalata, Wahl., and C. capillaris, L. To these may be added Oxyria digyna, Hill, Scheuchzeria palustris, L., and Carex incurva, Lightf., reported from the Lea Valley, but not on record from the Cam Valley.

The occurrence in. England during the Pleistocene of arctic species now extinct in Britain and known only from arctic Europe and Greenland is particularly interesting, as is also the fact that other species of the Cam Valley are unknown from Arctic Europe, occurring only in alpine situations in Central and South Europe.

Whether this arctic-alpine flora existed at the climax of a cold period the evidence from the plants alone, as Miss Chandler points out, is insufficient to say, but the association points to climatic conditions different from those which now prevail in the south of Britain, and clearly indicates that an invasion of northern forms had taken place since the time of the Cromerian flora.

Numerous arctic plant-beds occurring at low levels have been described from Scotland also, the most extensive investigations being those of Lewis (1905-11). Considerable fluctuations in the distribution of vegetation over North Britain during post-glacial times are indicated, for the changes described by Lewis occurred later than the last ice-sheet and give no information about the chain of events during the period of maximum glaciation. In Europe, Scandinavian workers have succeeded in tracing with some degree of precision successive floras which existed during the Pleistocene. A review of the historical sequence is given by Wille (1915) and short accounts of numerous continental investigations are included by Clements (1916) in his discussion of the ceneosere. The general conclusion may be reached (E. M. Reid, 1922) that plant migrations have been brought about in the past under stress of climatic change, and, while Britain undoubtedly shared in the southward movement developed during the glacial period, there is, as already mentioned, no incontrovertible evidence of the exact extent of this movement within our own country; Historical phytogeography does not provide a conclusive answer.

Nevertheless, certain students of the subject have adopted a definite standpoint. Engler (1879) assumes the complete or almost complete 
destruction of the pre-glacial flora of Britain and its re-immigration in postglacial times. Clement Reid also maintains that, with the possible exception of a few arctic plants, our flora is post-glacial in origin. 'We have merely to account', he says (1911), 'for the incoming of our existing flora after an earlier assemblage had been swept away almost as completely and effectually as the celebrated volcanic eruption wiped out the plants of Krakatao.' Stapf (1914) sees 'no way out of the conclusions at which Mr. Reid and many years before him Professor Engler have arrived', although he doubts whether certain elements in the British flora are explained 'by chance and occasional introduction of seeds', as is propounded by Clement Reid.

On the other hand, the hypothesis that much of the flora survived the glaciation of the country is not without its advocates. We have seen that Forbes, as long ago as I 846 , regarded our flora as derived from different parts of the Continent by successive overland migrations, and he came to look upon the Iberian element, which is found in the west of Ireland, as the oldest, dating back to a time when a mysterious 'Atlantis' connected Ireland and Spain. Students of the Irish flora and fauna have done much to substantiate Forbes's hypothesis. Zoological evidence bearing on the 'Atlantis' problem is discussed by Scharff (1902), and the same author (1912) disputes the idea of a wholesale destruction of the flora which occupied Britain in pre-glacial times. Kennard and Woodward (1917), dealing with the post-Pliocene non-marine Mollusca of Ireland, also support the survival hypothesis, and Praeger (1910), writing of the Pyrenean plants in the west, describes them as 'relics of a vegetation which once spread along a bygone European coast-line which stretched unbroken from Ireland to Spain'. Further evidence in support of survival from early Tertiary times is provided by three American species-Spiranthes Romanzoffiana, Cham., Sisyrinchium angustifolium, Mill., and Eriocaulon septangulare, With. These occur in Ireland, the last in the west of Scotland also, and it is held that they must be members and relics of a pre-glacial flora which occupied a northern continent linking Europe and America across the North Atlantic.

The problem of the origin and distribution of any flora is so intimately related to the question of slow overland migration versus other possible methods of dispersal, such as water-currents, wind, or migrating birds, that mention must be made of it. A particular case, not incomparable with that of Britain after glaciation, is that of the Faeröes, discussed by both Ostenfeld (1901) and Warming (1903). Both agree that the present flora is post-glacial and that re-colonization from sea-borne or bird-carried seeds has been insignificant. Warming believes the wind is responsible for the introduction of most of the plants now found on the islands, while Ostenfeld holds that invasion took place over a post-glacial land bridge. Holttum 
(1922), dealing with the vegetation of Greenland, regards the present flora as post-glacial, and states that of $4 \mathrm{I} 6$ vascular plants recorded, about 60 per cent. are southern types, most of which must have been carried over the sea by natural means.

The extent of former land connexions between Britain and Europe is a little doubtful, but even if it were but slight in recent Pleistocene times, the distance to be travelled by most of those forms which inhabit only the south of England would not be very great. We cannot here enter into the question as to how dispersal has been effected in the case of those plants held to be indigenous. As Guppy (1893) has pointed out, time has long since discounted the various methods, and I would add that the part which man has played from earliest times in the introduction of seeds can never be truly estimated. We cannot really discriminate between 'native' and introduced' species if we go far enough back.

More need not be said to illustrate the divergent' views which are held regarding the origin and dispersal of our native flora. Only further geological evidence one way or the other will clear the ground for the botanist. The problems remain, and to the fundamental question as to the effect of glaciation on the plant population at the time it seems impossible in the present state of our knowledge to give a definite answer. I should not have reverted to these old-standing problems had not plant-distribution in all parts of the world recently assumed a new interest and a new importance.

\section{The Present Investigation.}

The promulgation of the hypothesis of 'Age and Area' by Dr. Willis $(1915,1919)$, which has now been successfully tested in a variety of ways, opens up a new standpoint in the study of plant geography. In particular, it provides a new angle from which invasions and migrations may be viewed, and it is especially from this aspect that the following analysis has been made and not from any hope to solve the whole problem of distribution in Britain. In order to trace probable lines of invasion and inward spread, a cartographic presentation of the facts of distribution seemed desirable, if not necessary, and most of the points I wish to bring forward will be offered in the form of maps. The first step to tracing the progress of the creation of vegetation is to know the proportion in which groups appear in different localities, a relation which must be expressed in numbers to be at all tangible. ${ }^{1}$ We are not here concerned with the origin of new forms, but by ascertaining the number of species in different localities we may at least attempt to trace the progress of that invasion by which our flora has gradually been built up.

1 A statement of Sir J. D. Hooker. Extracted from a chapter by Dr. Guppy in Willis's Age and Area. Camb. Univ. Press, I922. 
As a working basis, a list of species generally admitted as indigenous was compiled from Babington's 'Manual' (1904), omitting micro-species of critical genera, since our knowledge of their distribution is far from complete. But for all the major species the data of distribution are available in Watson's 'Topographical Botany' (1883) and Bennett's Supplement to that work published in 1905 . Since then some new records have accrued, but the differences between my own list and that of Druce (1908) or the London Catalogue (1908) are not sufficient to affect the general results when mass distribution is under consideration. Further, the new additions are not likely to affect one area in particular; they will be more or less uniformly distributed.

\section{General Analysis of the British Flora.}

The number of British flowering plants, which alone are dealt with in these distribution studies, is 1,377 , of which 1,295 occur in England, I,024 in Scotland, and 944 in Ireland. These figures themselves indicate a diminution in the flora as distance from the Continent increases, and while this is true it is well to remember that numerous species occur in Scotland or in Ireland which are absent from England. Again, England and Scotland share over Ioo species which do not extend to Ireland, and 70 inhabit England and Ireland which are not recorded from Scotland. But of plants exhibiting a restricted range by far the largest number appears in England and Wales. This limited portion amounts to 266 species, nearly 20 per cent. of the total. On account of its restricted distribution, a study of this 'English' flora may throw some light on invasions and inward spread of plants in Britain as a whole, since we can learn little in this connexion from those species which now inhabit the majority, if not all, of the 1 I 2 vicecounties into which the country is divided for topographical statistics. It is an attempt to work backwards, as it were, picking up clues where we can from those plants which, whatever the cause, still show a limited range within our islands.

\section{Distribution OF 266 'English' Plants.}

For convenience, species restricted to England and Wales will be referred to as 'English' plants. Their mass distribution is expressed cartographically in Diagram 1, the inset map indicating the European distribution of the same group. The bulk of this English portion of our flora may have come through France, where over 90 per cent. of it is centred. The dispersal within England is then very much what would be expected, but when we bear in mind the long period of time during which much disturbance of our native flora has occurred, the interesting feature exhibited 
by the map is the remarkably regular diminution of the flora from the southeast, where it is concentrated, towards the north-west, where it is sparse. The mass distribution suggests a general invasion and migration north-westwards.

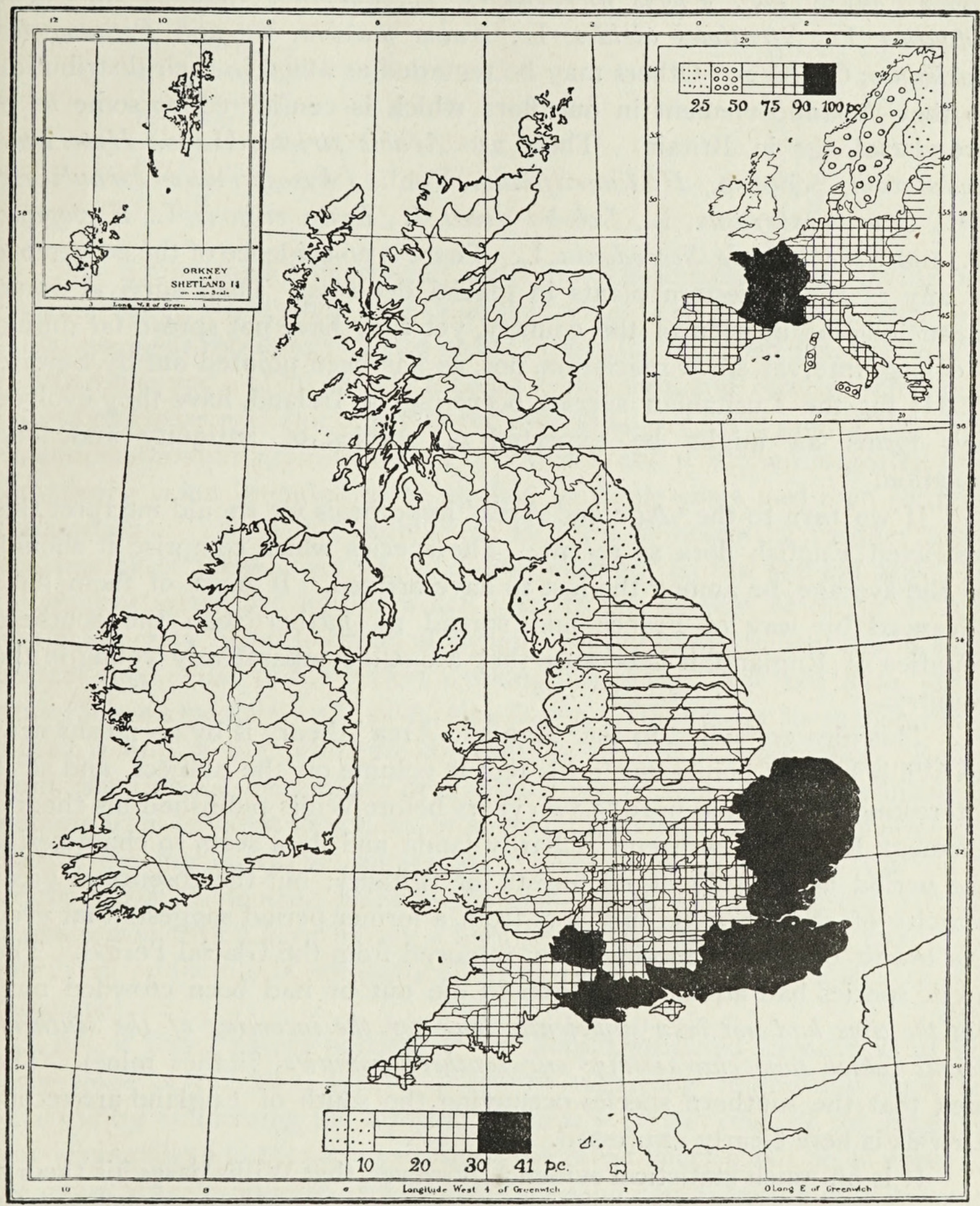

Diagram I. Distribution of 266 plants of the British Flora confined to England and Wales.

Whether the immigration of the British flora as a whole followed this direction only further analysis will show, but a clue which seems worth following is provided by the map before us.

There is at present little evidence to show whether any of these 
'English' species survived the Glacial Period in Britain. Some certainly • existed in the country during the Pliocene, being recorded either from the Cromerian or from the Castle Eden floras. These are Acer campestre, L., Imula Conyza, DC., Picris hieracioides, L., Carpinus Betulus, L., Fagus sylvatica, L., Stratiotes aloides, L., Naias marina, L., and Potamogeton trichoides, C. and S. Others may be regarded as allied in their distribution to that Atlantic element in our flora which is considered by some as of pre-glacial age in Britain. These are Arabis stricta, Huds., Hypericum undulatum, Schousb., H. linariifolium, Vahl., Physospermum cornubiense, DC., Cnicus tuberosus, L., Lobelia urens, L., Erica ciliaris, L., E. vagans, L., and Scrophularia Scorodonia, L. There is no evidence of the occurrence of any of these western plants in glacial deposits. Their survival would mean long occupation of the country, yet they have not spread far during the long interval since glaciation, nor, as has been pointed out by Seward (1911) for the Lusitanian species occurring in Ireland, have they evolved new forms as might be expected of species of antiquity and long isolation.

If we turn to the 'Age and Area' hypothesis we should interpret this restricted English flora as recent. The species which comprise it should, on the average, be among the last to have arrived. If most of them have advanced by way of France and spread no farther than the southern counties of England, it is because they are still comparatively young in the country.

This idea embodied in the 'Age and Area' theory is by no means new, as Willis himself points out in his recent volume on the subject, and it is interesting to find that in I 913 , two years before Willis published his theory, Clement Reid had written, 'A hardy fauna and flora seem to characterize the period of the submerged forests [of Britain]; but the absence or great scarcity of characteristic survivors from a former period suggests that even the lowest of these deposits is far removed from the Glacial Period. The arctic species had already had time to die out or had been crowded out; but the time had not been sufficiently long for the incoming of the southern forms which now characterize our southern counties' (italics mine). The idea that the southern species occupying the south of England are recent arrivals is here clearly expressed.

It is on much statistical evidence, however, that Willis bases his theory, and an examination of Diagram I clearly suggests that numerous species occupy a comparatively small number of counties to produce the concentration in the south-east, and, in contrast to this, few species are so widely dispersed as to occupy all the vice-counties of the country, seventyone in number. Working out the details and arranging the species in ten classes representing varying degrees of rarity, we obtain the results shown in Table I. 


\section{TABLE I.}

Occupying not more than

$\begin{array}{ll}\text { I. Seven } & \text { vice-counties } \\ \text { 2. Fourteen } & , \\ \text { 3. Twenty-one } & , \\ \text { 4. Twenty-eight } & , \\ \text { 6. Thirty-five } & , \\ \text { 7. Forty-two } & , \\ \text { 8. Fifty-nine } & , \\ \text { 9. Sixty-three } & , \\ \text { 10. Seventy-one } & ,\end{array}$

Number of species.

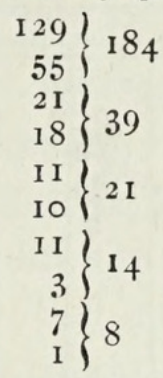

The figures form a decreasing series like those obtained by Willis for endemic species, but since they relate to 'wides' the principle of 'Age and Area' suggests recent arrival, not recent origin, for the great majority of the plants concerned. This is only a broad conclusion, and results which pertain to the mass may not apply to the individual. This is one of the chief objections brought against Willis's hypothesis, and it is often forgotten that the theory is not intended to be applied to single cases and then to draw comparisons. Yet, if it is applicable at all, it is necessary to offer some explanation of those cases which do not conform to the general law. In the present series, the figures which refer to ten degrees of rarity do not produce a very smooth curve, although roughly they follow the hollow pattern type. But to the perfect w'orking out of the 'Age and Area' principle there seems to be some disturbing factor. To discover these disturbing causes is one of the problems confronting the plant-geographer. Relics from past climatic successions, or commingling of more recent assemblages arriving from different directions, or some outstanding ecological differentiation of the flora may be suggested. Competition is perhaps the most potent factor influencing plant distribution. I have already shown (1922), in connexion with a flora having a high percentage of relics, that the 'Age and Area' principle is not particularly obvious until the relic species are eliminated.

But if this English portion of our flora, considered broadly, is at an early stage of invasion, greater precision regarding migrations may be obtained by submitting the rarest class (nearly 50 per cent. of the total as here arranged) to further analysis, since the rarest species will be, in general, the latest arrivals, and the area or areas showing concentration may provide a clue to the direction from which they came. Accordingly, the $129 \mathrm{mem}$ bers of the rarest class have been mapped separately. The result is shown in Diagram 2, where the actual number of species is given for each vicecounty. ${ }^{1}$ There is a considerable number of outlying species in the north

1 From my list of data these $\mathbf{2} 29$ species occupy, on the average, $3 \cdot 3$ vice-counties. Taking the London Catalogue numbers or those of Druce's List they occupy 3.5 vice-counties. 
and in Wales, among which may be mentioned Actaea spicata, L., Viola mpestris, Schmidt, Arenaria uliginosa, Schlecht, Arenaria gothica, Fr., Potentilla rupestris, L., Polemonium coeruleum, L., Cypripedium Calceolus,

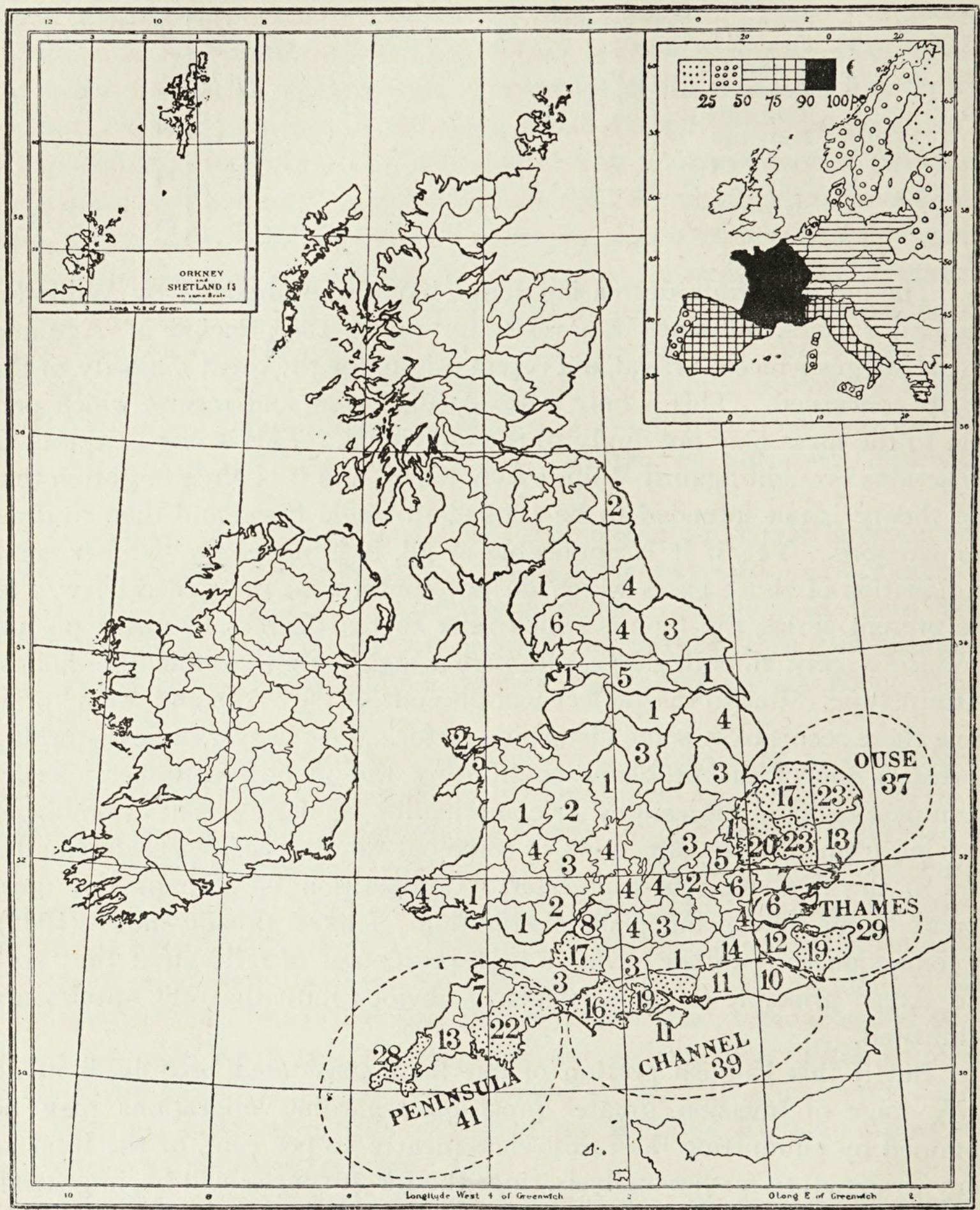

Dias;ram 2. Distribution of I 29 rare 'English' species.

L., Maianthemum bifolium, Sch., Lloydia alpina, Salisb., Potamogeton rutilis, Wolf., Carex ornithopoda, Willd., and Ammophila baltica, Link. Some of these enter into the montane or boreal flora of England. None of them is known from pre-glacial deposits, and one, Arenaria gothica, is recorded from the glacial beds of the Cam Valley. This species, occurring on the Continent 
only in Sweden and Switzerland, may be considered a glacial relic, a member of a residual flora, the bulk of which is found farther north, although in Pleistocene times it reached the south of England. Perhaps the other montane or arctic-alpine species are also old, although the fossil evidence is not yet forthcoming. On the other hand, a plant like Ammophila baltica of the Durham and Norfolk coasts may have arrived recently, if it has not actually originated in these localities, since it is often regarded as a hybrid. Again, Potamogeton rutilis in Anglesea may be a recent immigrant. ${ }^{1}$ Such outliers and others that will be mentioned later show the necessity for taking into consideration all the facts which bear on plant-distribution problems. They seem to point in some cases to survival, in other cases to sporadic introduction, rather than to any particular, directed movement. They will interfere, therefore, with the 'Age and Area' scheme in detail. But it is impossible to ignore the fact that most of the very rare flora in England is concentrated in the south-west, south, and south-east. West Cornwall stands highest with 28 species. East Kent has 19, yet this vicecounty possesses the largest number when the total of 266 species is analysed. Thus the important point emerges that all the more widelydistributed English species, once having reached Kent, have remained established there. There is no suggestion of a wholesale destruction once colonization has been effected. The dotted areas in Diagram 2 showing density need not be considered the last strongholds of assemblages of plants once more widespread. It seems more reasonable to suppose that they are points at which plants have arrived and have secured a foothold.

If this view is correct, it may be instructive to inquire whether any floral or geographical alliance exists amongst those areas which are especially rich in species. Guided by the results of Diagram 2, we may select a few districts for the purpose of illustrating this point. Four areas are shown enclosed by dotted lines. Each includes several vice-counties, so that the districts compared may not be too small nor the analysis too elaborate. The four regions do not correspond exactly in size with the provinces employed by Watson, being smaller, but it is convenient for reference to use his names, viz. Ouse, Thames, Channel, and Peninsula.

Of the 129 rare species under consideration, 37 oscur in the Ouse province, 29 in the Thames, 39 in the Channel, and $4 \mathrm{I}$ in the Peninsula. We may now trace the distribution of these assemblages, beginning with the Ouse group. Diagram 3 gives the vice-county details, but, taking the four larger areas proposed, we find that of the 37 species centred in the Ouse province, II occur in the Thames, 9 in the Channel, while 7 reach the Peninsula. In the same way Diagram 4 illustrates the distribution of the Thames group of 29 species, of which II pass northwards to the Ouse, 13 occur in the Channel, and 7 in the Peninsula. The range of the 39 species 
concentrated in the Channel area is shown in Diagram 5. Seventeen of these are found in the Peninsula, $I_{3}$ in the Thames, and 9 reach the Ouse district. Finally, in Diagram 6 there is shown the distribution of the $4 \mathrm{I}$

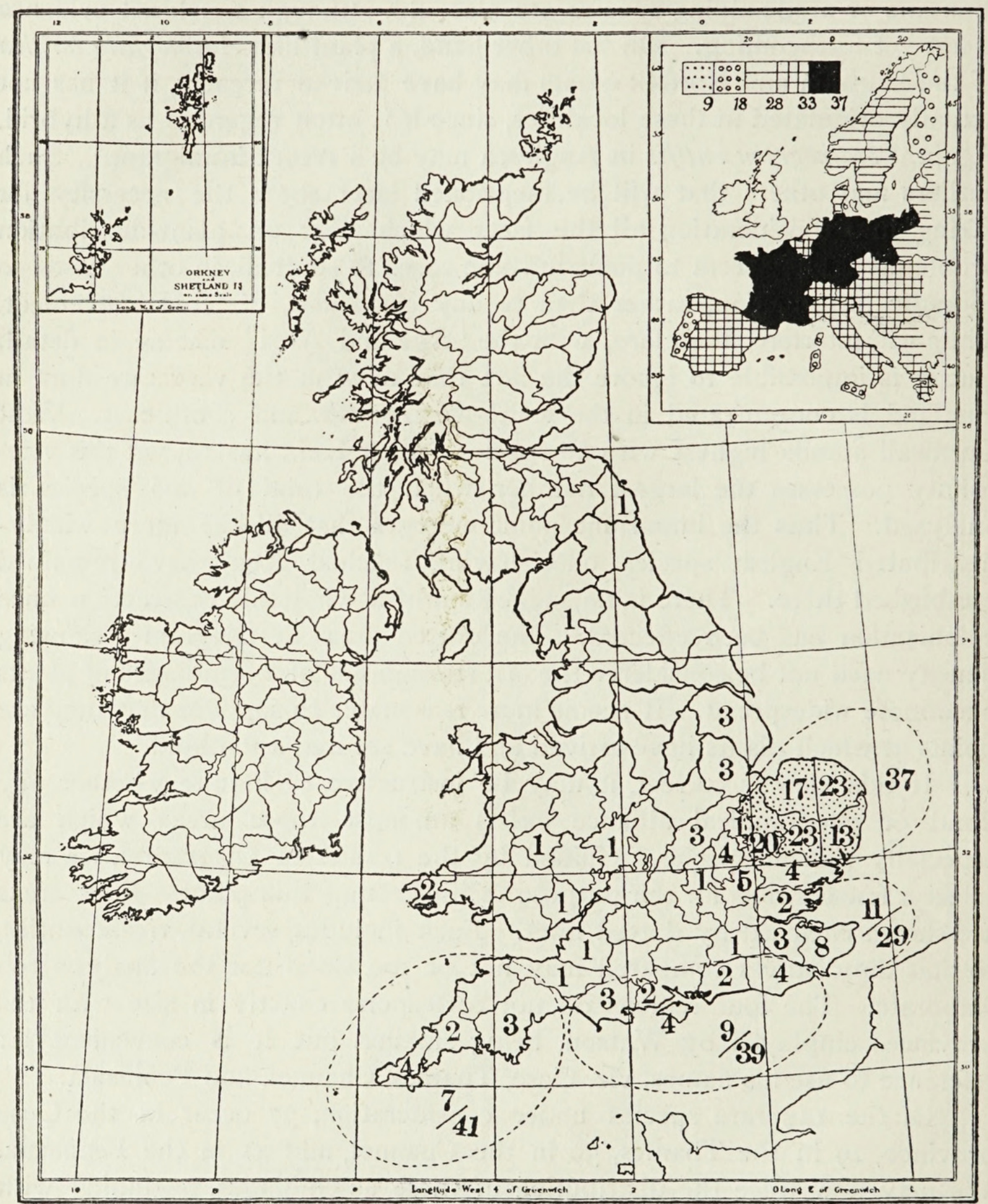

DIAGRAM 3. Distribution of 37 'Ouse' species.

species which have their head-quarters in the Peninsula. Of these $I 7$ are common to the Channel, only 7 reach the Thames, and 7 also appear in the Ouse province.

These facts are summarized in Table II. Since 30 of the 129 rare species do not occur in the districts defined, the total flora of the four areas combined numbers 99 species. 
TABLE II.

$\begin{array}{cccc}\text { Ouse. } & \text { Thames. } & \text { Channel. } & \text { Peninsula. } \\ 37 & 11 & 9 & 7 \\ 11 & 29 & 13 & 7 \\ 9 & \text { I3 } & 39 & 17 \\ 7 & 7 & 17 & 41\end{array}$

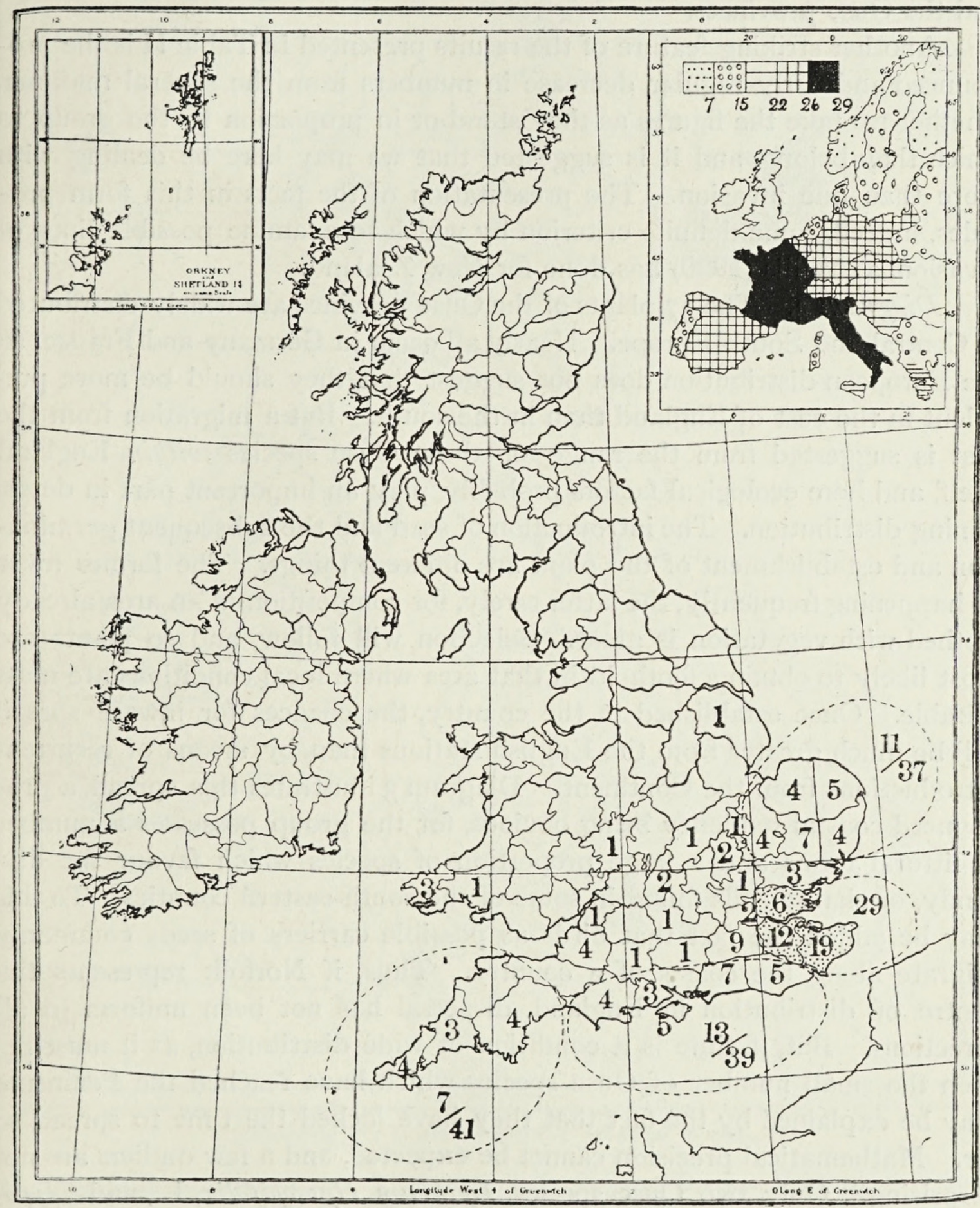

DIAGRAM 4. Distribution of 29 'Thames' species.

It is clear that these small assemblages are fairly diverse in floristic composition. In fact, only two species are common to all the districts, and to the approximately equal floras occupying the most widely-separated regions, Ouse and Peninsula, only 7 species are common. The index of 
floral diversity employed by Colgan (1901) is the 'ratio which the total of species not common to both areas bears to the total flora of the two areas combined'. This index for Ouse and Thames is 0.800 , for Thames and Channel 0.764 , for Channel and Peninsula 0.730 , for Peninsula and Ouse 0.901 . The greatest difference is between the groups of the Peninsula and the Ouse provinces.

Another striking feature of the results presented in Table II is the pronounced and fairly regular decrease in numbers from the several maxima, whether we take the figures as they stand or in proportion to the group to which they belong, and it is suggested that we may here be dealing with more than one invasion. The presentation of the facts in this form provides, indeed, some definite criterion by which to examine possible lines of invasion, as Willis (1920) has done for New Zealand.

Diagram 3. The 37 plants of the Ouse province are widely distributed in Central and South Europe. Nearly all occur in Germany and France, so the European distribution does not suggest that they should be more prevalent in the east of England than in the south. But a migration from the east is suggested from the range of these Ouse species within England itself, and here ecological factors probably play an important part in determining distribution. The introduction of seed and the subsequent germination and establishment of the plant are different things. The former must be happening frequently, the latter rarely, for competition in an area already clothed with vegetation is great. Selection will follow, and so plants are most likely to obtain a foothold in that area where local conditions are most suitable. Once established in the country, the chances for inward spread will be much greater from the English stations than by means of recurrent introductions from the Continent. Diagram 3 illustrates this spread, a pronounced coastal tendency being obvious, for the group possesses a number of littoral forms and a large proportion of species which favour the dry, sandy, or chalky soils found in some of the south-eastern counties. To this may be added the fact that birds as possible carriers of seeds commonly migrate along the coasts of a country. Thus, if Norfolk represents the centre of distribution in England, dispersal has not been uniform in all directions. But, if time is a condition of wide distribution, as it must be, then the small number of Ouse species which have reached the Peninsula may be explained by the fact that they have lacked the time to spread so far. Mathematical precision cannot be expected, and a few outliers are not surprising. Only two Ouse species, Lythrum Hyssopifolia, L., and Hypochaeris maculata, L., are absent from the Thames and Channel and occur in the Peninsula area. This may be due, though not necessarily, to separate introductions from continental sources, yet, if such occurrences were at all frequent, it is unlikely that the regular decrease from the maximum would be obtained. 
Diagram 4. All the Thames species, 29 in number, occur in France, and their concentration in Kent is not unexpected. Genista pilosa, L., Orobanche Picridis, Sch., and Cyperus longus, L., extend to Pembroke, while

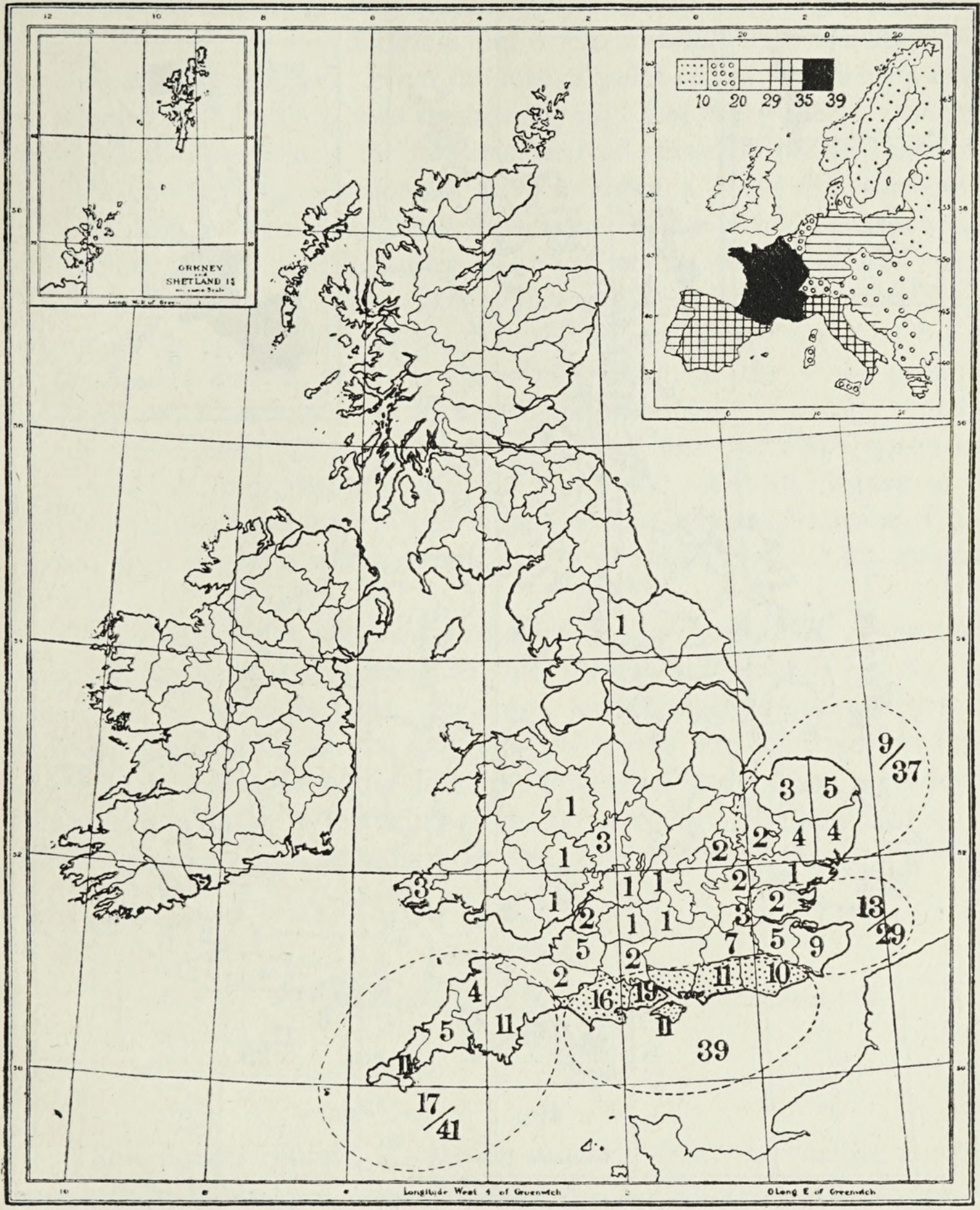

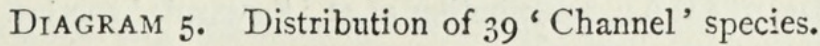

Ceratophyllum submersum, L., appears in Carmarthen. Except for these outliers, the thinning out of the Thames species from their head-quarters in Kent is fairly uniform and quite pronounced when the larger provinces rather than small vice-counties are considered.

Diagram 5. All but one of the 39 Channel species are found in France, and 14 are members of the southern element as defined by Stapf 
(1914). The group exhibits a sudden diminution in numbers in the interior of England, and a marked coastal tendency east and west.

Diagram 6. The Peninsula species, numbering 4I, have a European

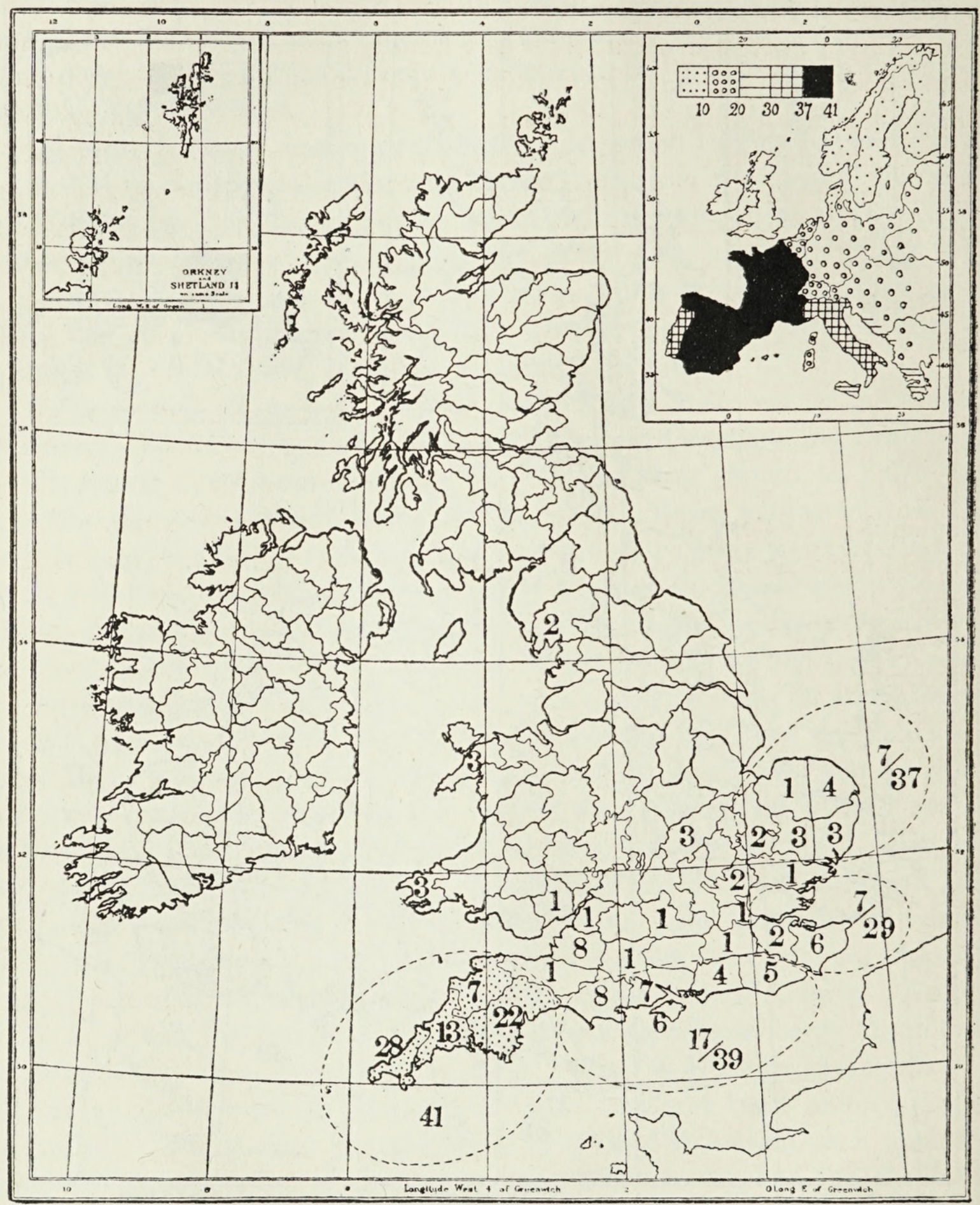

Diagram 6. Distribution of $4 \mathrm{I}$ 'Peninsula' species.

distribution which is essentially south-western, 22 of them belonging to Stapf's southern element, while 7 are definitely Atlantic. Nearly all occur in France and Spain, and more than half are absent from Central Europe. Their concentration in Cornwall may be attributed, then, to an almost direct northern extension from their chief European centre. Within England they thin out in the opposite direction to the Ouse group of plants, as a glance at 
Table II or Diagrams 4 and 6 will show. These two series of figures may well suggest the questions whether the two assemblages of plants to which they refer are concentrated in areas where they arrived and became established, or whether they constitute residual groups squeezed into these corners by a process of elimination and disintegration which has been more than remarkably regular. From the former point of view distinct invasions are suggested, although it need not be supposed that every species occurring in the Channel province, for instance, arrived there by direct migration. Common species may occasionally have followed a more circuitous route, arriving, perhaps, by way of the Peninsula or by way of the Thames area.

Attention may next be drawn to an interesting and important feature exhibited by Diagrams $3^{-6}$ taken consecutively. The concentration of species in the several districts in England is very fairly matched by the European distribution. The centre of dispersal for the Ouse group is Germany and France, but for the Peninsula assemblage it swings round to France and Spain. In their most general features the maps correspond with those of Stapf (1916), who worked with the southern element of the British flora as determined by its range on the Continent, whereas I have worked with a group whose boundaries are determined by its range in Britain.

The results so far obtained, indicative of the distribution of the rarest species in England, seem consistent with the general principle of 'Age and Area'. It is of importance, therefore, to test the question further by analysing the data for all the English species. Of the total number (266), only 33 are absent from the four provinces we have been considering, i. e. three in addition to the thirty of the rarest class. The dispersal of the remaining 233 through these four areas may be seen from the figures given in Table III.

\section{TABLE III.}

$\begin{array}{rccc}\text { Ouse. } & \text { Thames. } & \text { Channel. } & \text { Peninsula } \\ \mathbf{1 4 2} & 108 & \text { IOI } & 63 \\ \text { I08 } & \mathbf{1 4 4} & 116 & 73 \\ \text { I0I } & 116 & 157 & 89 \\ 63 & 73 & 89 & \mathbf{1 1 7}\end{array}$

These figures confirm the results obtained from the smaller numbers dealt with in Table II. They also serve to illustrate the general features already expressed cartographically in Diagram I, where it is shown that the 'English' flora, taken as a whole, is most abundant from Norfolk to Dorset. The Channel province is now seen to possess the largest number of species. It is through this area that the bulk of our English flora may be regarded as having advanced from the Continent, although we have seen that other movements west and north have played a part in the building up of the flora. 
It has already been suggested that plants may reach the Channel or Thames region by dispersal along a circuitous route, say through the Peninsula or the Ouse, as well as by direct migration. In the course of time, as a result of the meeting of different migrations, the intermediate districts, Thames and Channel, would attain a larger flora than the areas at the extremities of the region, assuming that plants are arriving in approximately equal numbers and spreading at roughly equal rates-conditions not likely to be fulfilled in nature. But even an approximation to such conditions would produce an average result in which the working out of the Age and Area principle would be obscured if applied to the total flora. In the present case, in fact, we have a group of 233 species distributed through the four districts of the area under consideration as follows:

75 occupy one district ;

43 occupy two districts ;

62 occupy three districts;

53 occupy four districts.

The figures are not particularly suggestive of 'Age and Area', yet when they are disentangled the applicability of the law becomes more apparent. The rarest species (99) are distributed as follows :

67 occupy one district;

I 9 occupy two districts ;

I I occupy three districts ;

2 occupy four districts.

Thus the rare species are seen to follow the general law much more closely. Whatever the cause of the rarity, if these species are the result of different invasions, the admixture in any one district due to migration from different directions will be relatively small. We should expect, then, that the general principle should apply to any particular invasion, although it has to be noted that the numbers involved become much smaller. That this is so has already been indicated in the results shown in Table II, but the facts may now be expressed in the usual 'Age and Area' way. They are given in Table IV.

\section{TABLE IV.}

$\begin{array}{lcccc}\text { Occupying } & 4 \text { I Peninsula } & \text { 39 Channel } & 29 \text { Thames } & \text { 37 Ouse } \\ \text { sppecies. } & \text { species. } & \text { species. } \\ \text { One district } & 2 \text { I } & \text { I4 } & \text { I I } & 2 \text { I } \\ \text { Two districts } & \text { II } & \text { I3 } & 7 & 7 \\ \text { Three districts } & 7 & 10 & 9 & 7 \\ \text { Four districts } & 2 & 2 & 2 & 2\end{array}$

The results agree fairly well with Willis's hypothesis. When a species occurs throughout the whole region it is, of course, not easy to determine to 
which invasion it belongs. In the rarest class there are only two such species, but in the whole group, as shown above, there are as many as 53 . The meeting and commingling of plants following different migratory paths then becomes so pronounced that it obscures any particular movement which may be applicable to certain assemblages considered separately. The distribution of the flora taken as a whole does not apparently follow the 'Age and Area' law, not because the law fails, but because it is obscured.

\section{Discussion.}

The data brought together in the preceding pages raise numerous questions about the distribution of plants in England, and I have presented the facts, I hope, without unduly pressing any particular conclusion, for the problem of distribution, even in a small area of the earth's surface, is eminently complex. No attempt can be made to deal with all the questions that arise. The study developed with the aid of the ideas underlying Willis's theory of distribution, and in broad outline that hypothesis seems applicable to the limited portion of the British flora which is under review. To discover invasions has been my chief aim, and while it would be rash to conclude that a definite number of migrations distinct in time and place has been fully demonstrated, there is nevertheless evidence to show that more than one invasion from continental sources has shared in the building up of our native flora. As to the time of these invasions there is little to guide us, although a consideration of all the evidence would suggest that they are comparatively recent. As to place, there seems reason to believe that plants have reached our shores generally along the coastal area from the Bristol Channel to the Wash. Certain areas of establishment are observable, and these show a geographical alliance with continental centres of distribution. Once established in England further spread seems to be effected from the English stations, although the possibility of recurrent introduction from the Continent cannot be entirely ruled out. The coastal tendency is a feature of the distribution of the smaller groups which have been studied in detail, and may be related to the ecological class of the species, and possibly to dispersal by birds which possess coasting habits. Hence species need not radiate uniformly from their centre of origin in the country.

But, allowing for many modifying factors, the results which the present analysis has produced seem capable of explanation along lines suggested by the principle of distribution which Willis has styled 'Age and Area'. An important modification is the exclusion on geological grounds of the boreal element in the flora, a procedure which is justified by the terms of the law itself.

Again, there is a small assemblage of species in North Somerset and Gloucester, few of which come within the boundaries of the areas I have 
especially dealt with. Arabis stricta, Huds., Draba airoides, L., Dianthus caesius, Sm., Euphorbia stricta, L., E. pilosa, L., Cephalanthera rubra, Rich., Allium sphaerocephahum, L., Carex tomentosa, L., and Koeleria vallesiana All. belong to this western group. The first only is western in Europe, the others being generally distributed throughout the Continent. Their localization in Britain is difficult to understand unless it is the result of chance introduction, although it may possibly be due to an extension of that movement which has helped to build up the peculiar element in the Peninsula flora.

Yet, of the total number of 'English' species, only I 2 per cent. lie outside the coastal counties from Cornwall to Norfolk. That 88 per cent. should occupy this belt and gradually thin out inland seems strong evidence that immigration has been, on the whole, a fairly definite movement. The process has doubtless gone on for thousands of years, and while occasional introduction may have been the general event, the chances would seem to be in favour of plants reaching points near or having some relation to their chief continental centres. The process may thus approximate to a definite tendency, and we might predict, as is often done, where certain species are most likely to occur. But not infrequently plants will be carried out of and beyond the general trend. They are the particular cases which do not follow the general rule nor conform to the general law. We have seen that in the 'English' portion of the British flora they are relatively few in number.

\section{SumMary.}

A brief survey of the divergent views held regarding the origin of the British flora is given, and the source and distribution of 266 species which are restricted to England and Wales are then considered. A map illustrates the range of these species, and the general conclusion is reached that this limited portion of our flora has been derived mainly by advance through France in post-glacial times. A detailed analysis shows that nearly 50 per cent. of the group is of great rarity. Excluding some 30 species which are boreal or western outliers (some as relics of a former arctic-alpine flora, others possibly as recent introductions), this rare element is centred along a coastal belt from Cornwall to Norfolk. Certain areas of concentration are found to exist indicating, it is believed, points of arrival and establishment rather than areas of retirement. These features provide a clue to invasions, and details are given for four small assemblages which may be regarded as having followed different migratory paths. An invasion from the east and another from the south are distinguished, and between these two lines the main portion of the English flora has probably advanced. In addition to the cartographic studies presented, the results are expressed in 
terms of Willis's 'Age and Area' theory of distribution. It is shown that by trying to discover disturbing factors and allowing for these, the results obtained are consistent with this hypothesis in its broad outlines, although on a first analysis the theory may not appear particularly applicable.

\section{LITERATURE CITED.}

Babington, C. C. (1904): Manual of British Botany. London.

Bennett, A. (1905) : Supplement to Topographical Botany. Journ. Bot., vol, xliii.

Chandler, M. E. J. (1921): The Arctic Flora of the Cam Valley. Quart. Journ. Geol. Soc., vol. lxxvii, pt. I, p. 4 .

Clements, F. E. (1916) : Plant Succession, Chapter XIII.

Colgan, N. (1901): Notes on Irish Topographical Botany, with some Remarks on Floral Diversity. Irish Nat., vol. x, p. 233 .

DRUCE, G. C. (1908) : List of British Plants. Oxford.

ENGLer, A. (1879): Versuch einer Entwicklungsgeschichte der Pflanzenwelt, vol. i, p. I75.

Forbes, E. (1846): On the Connexion between the Distribution of the existing Fauna and Flora of the British Isles and the Geological Changes which have affected their Area. Memoirs, Geological Survey, vol. i, p. 336 .

Guppy, H. B. (1893): The Distribution of Aquatic Plants and Animals. Scot. Geog. Mag., vol. ix, p. 28.

Holtтum, R. E. (1922): The Vegetation of West Greenland. Journ. Ecol., vol. x, p. 87.

Kennard, A. S., and Woodward, B. B. (1917): Post-pliocene Non-marine Mollusca of Ireland. Proc. Geol. Assoc., vol. xxviii, p. 109.

Lewis, F. J. (1905-11): The Plant Remains in the Scottish Peat Mosses. Trans. Roy. Soc. Edin., pt. I, vol. xli, p. 699 ; pt. 2, vol. xlv, p. 335 ; pt. 3 , vol. xlvi, p. 33 ; pt. 4 , vol. xlvii, p. 793 .

Marr, J. E., and Gardner, E. W. (1916): An Arctic Flora in the Pleistocene Beds of Barnwell, Cambridge. Geol. Mag., N.S., vol. iii, p. 339 .

Matthews, J. R. (1922): The Distribution of Plants in Perthshire in relation to 'Age and Area'. Ann. Bot., vol. xxxvi, p. 32 I.

Moss, C. E. (1914): Oxford Survey of the British Empire, vol. i, Chapter III, p. $9^{2}$.

Ostenfeld, C. H. (1901): Botany of the Faeröes, pt. I, p. Ioo.

Praeger, R. Ll. (1910): The Wild Flowers of the West of Ireland and their History. Journ. Roy. Hort. Soc., vol. xxxvi, p. 299.

REID, C. (1899): The Origin of the British Flora. London.

(1911): On the Relation of the Present Plant Population of the British Isles to the Glacial Period. Brit. Assoc. Report, p. 573.

(1913) : Submerged Forests. Camb. Univ. Press.

(1916): The Plants of the Late Glacial Deposits of the Lea Valley. Quart. Journ. Geol. Soc., vol. $1 \mathrm{xxi}$, pt. 2 , p. ${ }^{5} 5$.

and REID, E. M. (1908): On the Pre-glacial Flora of Britain. Journ. Linn. Soc., vol. xxxviii, p. 206.

(1915): The Pliocene Floras of the Dutch-Prussian Border. Med. Rijksopsporing van Delfstoffen, No. 6, p. $\mathbf{1} 5$.

ReID, E. M. (1920 a) : Two Preglacial Floras from Castle Eden. Quart. Journ. Geol. Soc., vol. lxxvi, pt. 2, p. 104.

(1920 b) : A Comparative Review of Pliocene Floras. Ibid., p. I 45. (1922): Chapter XIV in Willis's 'Age and Area'. Camb. Univ. Press. 
Scharff, R. F. (1902): Some Remarks on the Atlantis Problem. Proc. Roy. Irish Acad., vol. xxiv, B., p. 268.

(1912): The Relation of the Present Plant Population of the British Isles to the Glacial Epoch. Irish Nat., vol. xxi, p. I05.

Seward, A. C. (1911): Links with the Past in the Plant World. Camb. Univ. Press.

Stapf, O. (1914): The Southern Element in the British Flora. Engler's Botanische Jahrbuicher, Bd. 1, Supplement-Band. p. 509 .

(1916): A Cartographic Study of the Southern Element in the British Flora. Proc. Linn. Soc., I $29^{\text {th }}$ Session, p. 8r.

WARMing, E. (1903) : Botany of the Faeröes, pt. 2, p. 660.

Watson, H. C. (1835) : Remarks on the Geographical Distribution of British Plants. London. (1847): Cybele Britannica. 4 vols. London.

(1883) : Topographical Botany, Ed. 2. London.

Wille, N. (1915): The Flora of Norway and its Immigration. Ann. Missouri Bot. Gard., vol. ii, p. 59 .

Willis, J. C. (1915): The Endemic Flora of Ceylon. Phil. Trans. Roy. Soc. London, B., vol. ccvi, p. 307 .

(1916): The Distribution of Species in New Zealand. Ann. Bot., vol. xxx, p. 437.

(1919): The Floras of the Outlying Islands of New Zealand and their Distribution.

Jbid., vol. xxxiii, p. 267 .

(1920) : Plant Invasions of New Zealand. Ibid., vol. xxxiv, p. $47 \mathrm{r}$.

Numerous other papers by the same author in the Annals of Botany.

literature.

(1922) : Age and Area. Cambridge University Press. Contains an extensive list of 


\section{$2 \mathrm{BHL}$ Biodiversity Heritage Library}

Matthews, J. R. 1923. "The distribution of certain portions of the British flora." Annals of botany 37, 277-298.

https://doi.org/10.1093/oxfordjournals.aob.a089846.

View This Item Online: https://www.biodiversitylibrary.org/item/270686

DOI: https://doi.org/10.1093/oxfordjournals.aob.a089846

Permalink: https://www.biodiversitylibrary.org/partpdf/319083

\section{Holding Institution}

New York Botanical Garden, LuEsther T. Mertz Library

\section{Sponsored by}

BHL-SIL-FEDLINK

\section{Copyright \& Reuse}

Copyright Status: Public domain. The BHL considers that this work is no longer under copyright protection.

This document was created from content at the Biodiversity Heritage Library, the world's largest open access digital library for biodiversity literature and archives. Visit BHL at https://www.biodiversitylibrary.org. 